MATEC Web of Conferences 6, 02004 (2013)

DOI: $10.1051 /$ matecconf/20130602004

(C) Owned by the authors, published by EDP Sciences, 2013

\title{
Influence of length and dosage of polypropylene fibres on the spalling tendency and the residual properties of self-compacting concrete after heated at elevated temperatures
}

\author{
K.K. Sideris and P. Manita \\ Laboratory of Building Materials, Department of Civil Engineering, Democritus University of \\ Thrace, PO Box 252, Xanthi 67100, Greece
}

\begin{abstract}
The objective of this paper was to study the influence of different length and dosage of polypropylene fibres on the properties of self-compacting concretes at elevated temperatures. A total of five self compacting concretes and one normally vibrated concrete were produced. The poypropylene fibres were of different length $(12 \mathrm{~mm}, 6 \mathrm{~mm}$ and $3 \mathrm{~mm})$ and were added at dosages of $1.0 \mathrm{Kg} / \mathrm{m}^{3}$ and $0.5 \mathrm{Kg} / \mathrm{m}^{3}$. The properties measured after fire exposure were the compressive strength, splitting tensile strength and water capillary absorption. The best overall performance was observed on the fibre reinforced self compacting concrete produced with the $6 \mathrm{~mm}$ HPR fibres at a dosage of $0.5 \mathrm{Kg} / \mathrm{m}^{3}$.
\end{abstract}

\section{INTRODUCTION}

Self-Consolidating Concrete (SCC) is a type of concrete developed through the last 15 years. It is widely used in different applications ranging from housing to large infrastructures, such as bridges and tunnels because it can spread into place under its own weight and fill restricted sections without the need of mechanical consolidation, improving this way the working environment, reducing the manpower need for casting and increasing the speed of construction and the quality of cast structures (1). SCC is usually considered as a special type of high-performance concrete produced with higher amounts of filler materials and lower water/binder ratios as compared with other concretes. Thus porosity of SCC is usually reduced and the material is characterized from high diffusion resistance. This fact is responsible for the superior durability usually observed on SCC (2-8). On the other hand concrete mixtures of high diffusion resistance are usually considered as more vulnerable to fire attack. Concrete has in general good fire resistance. Its residual compressive strength is slightly reduced after fire exposure up to $400{ }^{\circ} \mathrm{C}(4,9)$ whereas it effectively protects reinforcement against elevated temperatures. However, fire resistance of concrete is decreased because of spalling. The main reason for concrete's spalling at elevated temperatures is considered to be the internal pore pressure buildup due to the vaporization of the free and chemically bound water (10). In concrete mixtures with finer pore structure, such as HPC, this internal pressure is not released, thus leading to spalling of concrete surface $(9,11-14)$.

Spalling behavior of certain concretes under fire conditions is a reason for inhibiting their use in structures where increased fire resistance is required for safety reasons, such as high rise buildings and tunnels. A lot of research has been carried out in order to model the spalling tendency of HPC and to propose some alternative solutions such as different mixture proportions or use of materials that provide a passive or active protection against spalling. Among the solutions proposed, the addition of polypropylene fibres seems to be an effective one (15-20). It was reported (21) that polypropylene melts at $160-168^{\circ} \mathrm{C}$ whereas HPC spalls when the air temperature ranges between $190-250^{\circ} \mathrm{C}$.

This is an Open Access article distributed under the terms of the Creative Commons Attribution License 2.0, which permits unrestricted use, distribution, and reproduction in any medium, provided the original work is properly cited. 


\section{MATEC Web of Conferences}

Melting of polypropylene fibres creates an additional pathway for release of internal vapor stresses at higher temperatures. Eurocode 2 [22] recommends including more than $2 \mathrm{~kg} / \mathrm{m}^{3}$ of monofilament polypropylene fibres in HSC to reduce spalling but the size of the fibres is not specified. Many researches reported that concrete spalling may be avoided when adding even smaller amount of fibres [23-26].

In this paper the mechanical characteristics of six self-compacting and normally vibrated concretes subjected to elevated temperatures up to $600^{\circ} \mathrm{C}$ were experimentally investigated. The initial effort was to produce self- compacting concretes with cement and water content as close as possible to the quantities used for the production of NVC mixtures of the same strength class. Polypropylene fibres of different length $(12 \mathrm{~mm}, 6 \mathrm{~mm}$ and $3 \mathrm{~mm})$ were added in four SCC in different dosages of 1.0 and $0.5 \mathrm{Kg} / \mathrm{m}^{3}$.

\section{EXPERIMENTAL PROGRAM}

Six different concrete mixtures were produced: five self- compacting concretes (SCC) and one normally vibrated concrete (NVC). The concretes belonged in the strength class C25/30, according to EN206-1 (27). The mixtures were prepared using two classes of Blended Portland Cement, i.e. CEM II/A-M 32.5N and CEM II/B-M 42.5N according to European standard EN 197-1 (28). The initial effort was to keep the cement dosage and water content stable among SCC and NVC. The coarse aggregates consisted of crushed granite with maximum size of $16 \mathrm{~mm}$. The fine aggregates used were crushed limestone sand. A high range of water reducing carboxylic ether polymer admixture was added at different dosages in order to achieve a slump of 190-200 $\mathrm{mm}$ in the case of NVC, or to achieve self compatibility in the case of SCCs. Polypropylene fibres of different type and length were added at different dosages. The one type of fibres was conventional polypropylene fibres (PF) and was used in two different lengths: $12 \mathrm{~mm}$ and $6 \mathrm{~mm}$. The fibres were added in the mixture at a dosage of $1 \mathrm{~kg} / \mathrm{m}^{3}$, according to the recommendation of the producer. The other type of polypropylene fibres (Heat Prompt Reaction fibres, HPR) was a special type offering, according to the producer, improved performance against high temperatures and improved workability and decreased cost due to the reduced quantity of fibres required. The fibres were used in two different lengths: $6 \mathrm{~mm}$ and $3 \mathrm{~mm}$ and were added in the mixture at a dosage of $0.5 \mathrm{~kg} / \mathrm{m}^{3}$, according to the recommendation of the producer. SCCs were prepared and tested in fresh condition according to the specifications of EFNARC (29). The proportions of concrete mixtures and the properties of fresh mixtures are presented for all concretes in Table 1.

The mechanical properties measured were: the compressive strength at the age of 28 days, the compressive strength and the splitting tensile strength at the age of 150 days as well as the residual compressive strength and the residual splitting tensile strength after fire tests at the same age. Also, the capillary water absorption was measured at the age of 28 days.

The specimens prepared were cubes with edge of $150 \mathrm{~mm}$ and cylinders with dimensions $150 \times$ $300 \mathrm{~mm}$. The measurements of compressive strength and water capillary absorption were realised on cubes, while the splitting tensile strength was measured on the cylinders. The specimens used for the compressive strength of 28 days and the capillary water absorption were cured in the curing chamber (relative humidity $=100 \%$ and temperature $=20 \pm 2{ }^{\circ} \mathrm{C}$ ) until the day of the measurement. The specimens used for the fire tests were initially cured for the first 14 days in the curing chamber. From this age onwards they were placed in the laboratory air environment (relative humidity $=50-60 \%$ and temperature $=20 \pm 2{ }^{\circ} \mathrm{C}$ ).

At the age of 150 days, the appropriate specimens were placed in an electrical furnace with heat applied at a rate of $5^{\circ} \mathrm{C} / \mathrm{min}$ until the desired temperature was reached. Before fire testing, three cubes were dried at $105^{\circ} \mathrm{C}$ until constant mass and then the moisture content was determined; it ranged between $3-4 \%$ for all mixtures. In the electrical furnace the maximum temperature of 300 , or $600{ }^{\circ} \mathrm{C}$ was maintained for 1 hour. Specimens were then allowed to cool in the furnace and tested for compressive strength and splitting tensile strength. At the same time, control tests were performed on specimens cured at room temperature $\left(20^{\circ} \mathrm{C}\right)$. 
IWCS 2013

Table 1. Mix design characteristics of self-compacting and normally vibrated concretes.

\begin{tabular}{|c|c|c|c|c|c|c|}
\hline $\begin{array}{c}\text { Mix design } \\
\left(\mathrm{Kg} / \mathrm{m}^{3}\right)\end{array}$ & $\begin{array}{l}\text { SCC } \\
\text { SCC } 1\end{array}$ & $\begin{aligned} & \text { SCC } \\
&+ \text { PF } 6 \text { mm } \\
& \text { SCC } 2\end{aligned}$ & $\begin{array}{c}\text { SCC } \\
\text { PF } 12 \text { mm } \\
\text { SCC } 3\end{array}$ & $\begin{array}{c}\text { SCC } \\
+\mathrm{HPR} 3 \mathrm{~mm} \\
\mathrm{SCC} 4\end{array}$ & $\begin{array}{c}\text { SCC } \\
+\mathrm{HPR} 6 \mathrm{~mm} \\
\text { SCC } 5\end{array}$ & $\begin{array}{l}\text { NVC } \\
\text { NVC }\end{array}$ \\
\hline CEM II 32,5N & 300 & 300 & 300 & 300 & 300 & 300 \\
\hline CEM II $42,5 \mathrm{~N}$ & 50 & 50 & 50 & 50 & 50 & 50 \\
\hline Coarse aggregates & 800 & 800 & 800 & 800 & 800 & 850 \\
\hline Sand & 881 & 881 & 881 & 881 & 881 & 980 \\
\hline Limestone filler & 100 & 100 & 100 & 100 & 100 & - \\
\hline Water & 193 & 193 & 193 & 193 & 193 & 191 \\
\hline Sup/er & 5.50 & 7.5 & 6.77 & 6.54 & 6.54 & 4.00 \\
\hline Retarder & 0.55 & 0.55 & 0.55 & 0.93 & 0.57 & 0.86 \\
\hline VMA & 1.14 & 1.35 & 1.14 & 1.14 & 1.14 & - \\
\hline Pol. fibers & - & 1.00 & 1.00 & 0.50 & 0.50 & - \\
\hline $\mathrm{W} / \mathrm{C}$ & 0.55 & 0.55 & 0.55 & 0.55 & 0.55 & 0.55 \\
\hline Slump (mm) & 760 & 730 & 730 & 770 & 740 & 220 \\
\hline V-Funnel (sec) & 12 & 9 & 9 & 11 & 11 & - \\
\hline $\mathrm{L}-\mathrm{BOX}\left(\mathrm{H}_{1} / \mathrm{H}_{2}\right)$ & 0.84 & 0.90 & 0.96 & 0.94 & 0.90 & - \\
\hline $\mathrm{f}_{c 28}(\mathrm{MPa})$ & 46.23 & 44.0 & 42.10 & 40.90 & 41.51 & 39.5 \\
\hline
\end{tabular}

The capillary water absorption, measured according to the procedure described by RILEM TC116 (30), was determined as the mean value of three cubes. Residual compressive strength was determined as the mean value of three cubes tested per temperature, whereas splitting tensile strength was determined as the mean value of two tested cylinders.

\section{RESULTS AND DISCUSSION}

Permeability of concrete is controlled by the capillary porosity of hardened cement paste, according to Neville (31). The pores relevant to permeability are those with a diameter of at least 120 or $160 \mathrm{~nm}$ and have to be continuous. Reinhardt and Stegmaier (32) produced eight different SCC mixtures and one reference conventional concrete and performed fire tests according to the time temperature curve described in ISO 834. The maximum temperature reached was $1080^{\circ} \mathrm{C}$ after 120 minutes. They concluded that as the matrix of the concrete mixtures gets denser, their fire behaviour gets worse: there was a clear trend that the residual compressive strength of all concrete mixtures tested in their research increased when the w/c also increased. The relationship between w/cm and propensity for explosive spalling was also reported by Phan and Carino (33). It has been theorized (9-10, 34-35) that the higher susceptibility of high strength concretes to explosive spalling is due, in part, to their lower permeability, which limits the ability of water vapour to escape from the pores.

The capillary water absorption is presented for all mixtures in Figures $1 \mathrm{a}$ and $1 \mathrm{~b}$ and gives an indication of the behaviour of mixtures during the fire exposure. Both NVC and SCC1 were characterized by higher water permeability; however the danger for spalling appeared increased since some cylindrical specimens of NVC and SCC1 were destroyed when heated above $500{ }^{\circ} \mathrm{C}$. On the contrary, explosive spalling was reduced in all SCC mixtures produced with polypropylene fibres. These mixtures were characterized by lower water permeability. The additional porosity formed after fibres melt resulted to better spalling behaviour, but was also responsible for the reduced residual strength observed. Only one cylinder was destroyed in SCC4 at temperatures above $550^{\circ} \mathrm{C}$ and some surface spalling was observed in SCC5 at the same temperature level. 


\section{MATEC Web of Conferences}

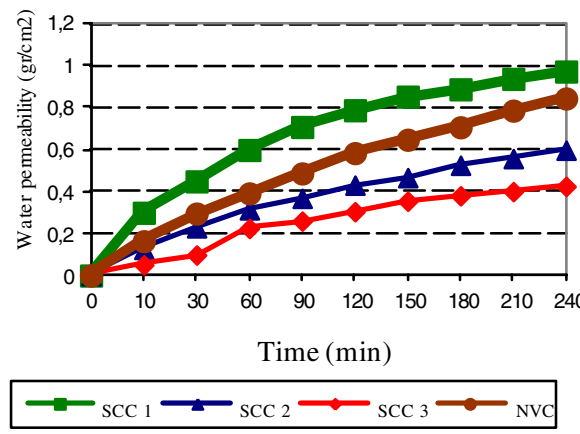

a)

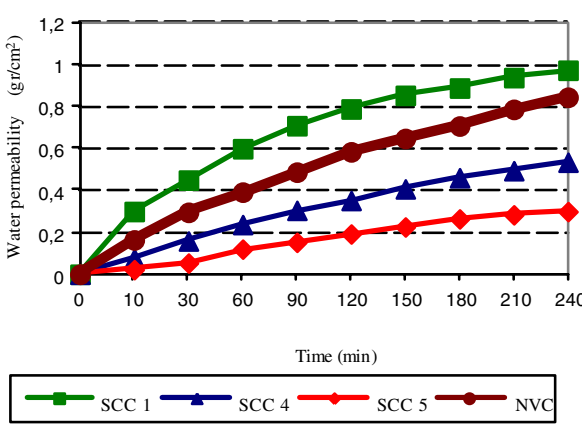

b)

Figure 1. Capillary water absorption of self-compacting and normally vibrated concretes.

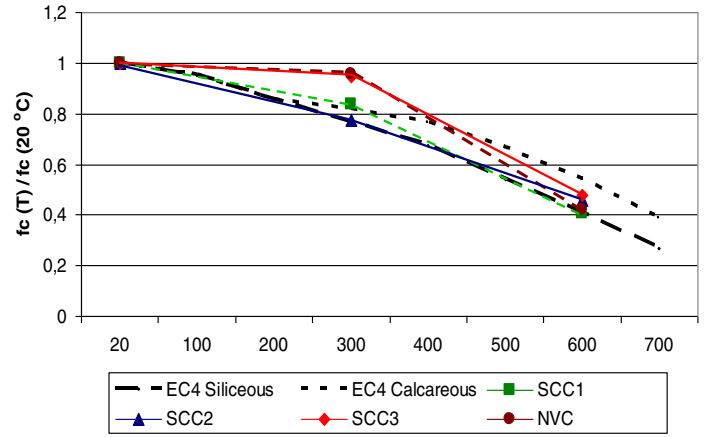

a)

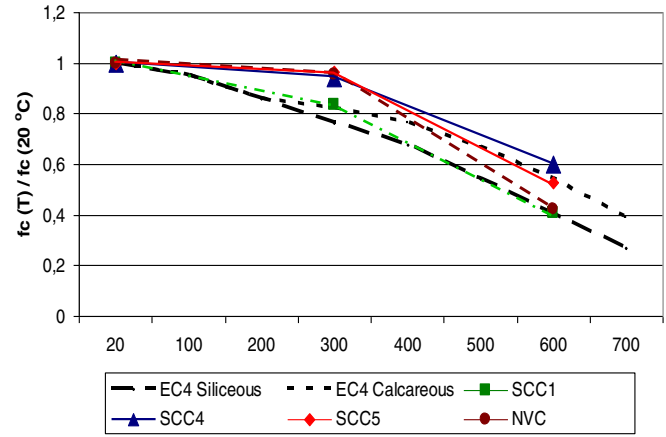

b)

Figure 2. Ratio of residual compressive strength after peak temperature $\left(\mathrm{f}_{\mathrm{ct}(\mathrm{T})}\right)$ to the compressive strength at room temperature $\left(\mathrm{f}_{\mathrm{ct}(20)}\right)$ of self-compacting and normally vibrated concretes.

The ratio of residual compressive strength of all concrete specimens as compared to the compressive strength at room temperature $\left(20^{\circ} \mathrm{C}\right)$ is presented for all mixtures in Figures $2 \mathrm{a}$ and $2 \mathrm{~b}$. The mixture NVC illustrated a significant high strength value after the exposure at $300{ }^{\circ} \mathrm{C}$, nearly the initial one of $20^{\circ} \mathrm{C}$, but at $600^{\circ} \mathrm{C}$ it lost the $60 \%$ of its initial compressive strength. The mixture SCC1 showed a considerable decreased strength value at $300^{\circ} \mathrm{C}$ comparing to $\mathrm{NVC}$, while at $600{ }^{\circ} \mathrm{C}$ the values of two concretes were close. SCC2 followed the same trend with SCC1. The SCC3 differentiates from SCC2 at $300{ }^{\circ} \mathrm{C}$ presenting a high strength value similar to its initial compressive strength, but at $600{ }^{\circ} \mathrm{C}$ it gave similar value to the one of SCC2. The SCC4 and SCC5 showed the better behaviour: they achieved the maintenance of the values near the initials at the temperature of $300{ }^{\circ} \mathrm{C}$, and they reached the higher values at the temperature of $600{ }^{\circ} \mathrm{C}$, losing $45 \%$ of the initial strength. As it was mentioned above, polypropylene fibres melt at $160-168^{\circ} \mathrm{C}$ and in this manner an additional pathway is created aiding the internal vapour pressure to expand. This was crucial for SCC3, SCC4 and SCC5 but not for SCC2. The last mixture lost its strength at a way similar to SCC1.

The SCC mixtures produced with polypropylene fibres -except SCC2- performed a sharp decrease of their residual compressive strength after treated at both target temperatures. These results are in agreement with findings of other researchers (36-37). Residual values of compressive strength of all mixtures are generally in good agreement with the values proposed in EC4. Pamonte and Gambarova [38] performed an extended research targeting to compare the residual compressive strength of SCC 


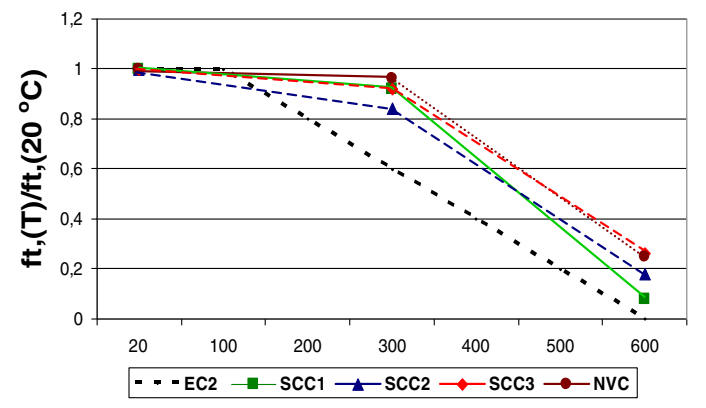

a)

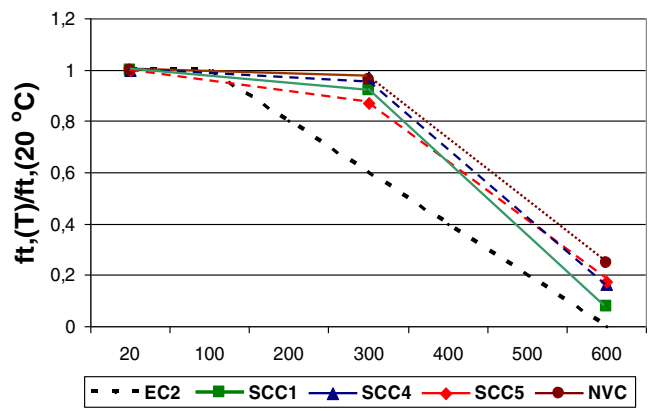

b)

Figure 3. Ratio of residual splitting tensile strength after peak temperature $\left(\mathrm{f}_{\mathrm{ct}(\mathrm{T})}\right)$ to the splitting tensile strength at room temperature $\left(\mathrm{f}_{\mathrm{ct}(20)}\right)$ of self-compacting and normally vibrated concretes.

mixtures as reported in different projects $[13,39-42]$. They also concluded that in most cases the residual strength curve was close to the values proposed in EC4.

The ratio of residual tensile strength of all concrete specimens as compared to the tensile strength at room temperature $\left(20^{\circ} \mathrm{C}\right)$ is shown in Figures $3 \mathrm{a}$ and $3 \mathrm{~b}$. Spalling occurred above $500{ }^{\circ} \mathrm{C}$ for the mixtures NVC and SCC 1 and destroyed some cylindrical specimens. It was observed that relative splitting tensile strength $\mathrm{f}_{\mathrm{ct}}(\mathrm{T}) / \mathrm{f}_{\mathrm{ct}}(20)$ was reduced up to $300^{\circ} \mathrm{C}$ following a similar path for all concretes. Among concrete mixtures tested, SCC2 and SCC5 were more susceptible in reducing their relative splitting tensile strength about $14-18 \%$, at temperatures up to $300^{\circ} \mathrm{C}$. The other concretes presented a slight strength loss ranging from 3 to $9 \%$. After the exposure to $600{ }^{\circ} \mathrm{C}$, all mixtures lost more than $70 \%$ of their initial tensile strength: NVC and SCC3 retained $38 \%$ of its initial strength whereas SCC1 mixture retained only $8 \%$. The corresponding percentage for the mixtures SCC2, SCC4 and SCC5 was $15-18 \%$.

\section{CONCLUSIONS}

As expected, conventional concrete and self compacting concrete suffered explosive spalling after heated at $6000 \mathrm{C}$. The spalling tendency was decreased for fiber reinforced self compacted concretes. The spalling phenomenon was not observed at all when PF $12 \mathrm{~mm}$ or $6 \mathrm{~mm}$ fibres were added at a dosage of $1 \mathrm{Kg} / \mathrm{m} 3$ in concrete. The HPR $6 \mathrm{~mm}$ fibres were found to be also effective when added at a lower dosage of $0.5 \mathrm{Kg} / \mathrm{m} 3$. The HPR $3 \mathrm{~mm}$ fibres added at the same low dosage did not manage to totally eliminate spalling. The best overall performance was observed on the fibre reinforced self compacting concrete produced with the HPR $6 \mathrm{~mm}$ fibres at a dosage of $0.5 \mathrm{Kg} / \mathrm{m} 3$. Spalling disintegration was not observed while the residual properties were in this case the best among all concrete mixtures tested.

Addition of polypropylene fibres had negative effect on concrete's residual mechanical properties since they significantly decreased the residual compressive strength and tensile strength of concrete, due to the increased porosity created after melting. It is therefore recommended to use polypropylene fibres as part of a total spalling protection design method in combination with other materials such as external thermal barriers.

\section{References}

[1] Skarendhal, A. "The present-the future", Proc., Third Int. Symp. on SCC, RILEM, Reycjavik, Iceland, (2003), Wallenik O. and Nielsson I. Editors, 6-14. 


\section{MATEC Web of Conferences}

[2] Träghård, Jan., "Microstructural features and related properties of self-consolidating concretes", Proc. First Int. Symp. on SCC, RILEM, Stockholm, Sweden, (1999), Skarendahl Å. and Petersson ö. Editors, 175-186.

[3] Zhu, W., Quinn, J. Bartos, P., "Transport Properties and Durability of Self Consolidating Concrete", Proc., 2nd Int. Symp. on SCC, Tokyo, Japan, (2001), Ozawa K. and Ouchi M. Editors, 451-458.

[4] De Schutter, G., Audenaert, K., Boel, V., Vandewalle L., Dupont, D., Heirman, G., Vantomme, J., D'Hemricourt, J., "Transport properties in self consolidating concrete and relation with durability: Overview of a Belgian research project", Proc., Third Int. Symp. on SCC, RILEM, Reycjavik, Iceland, (2003), Wallenik O. and Nielsson I. Editors, 799-807.

[5] Audenaert, K., De Schutter, G., "Chloride penetration in self consolidating concrete", Proc., Third Int. Symp. on SCC, RILEM, Reycjavik, Iceland, (2003), 818-825.

[6] Träghård, J., Skoglund, P., Westerholm, M. , "Frost resistance, chloride transport and related microstructure of field self-consolidating concrete", Proc., Third Int. Symp. on SCC, RILEM, Reycjavik, Iceland, (2003), Wallenik O. and Nielsson I. Editors, 881-894.

[7] Audenaert K., Boel, V.,. De Schutter, G., "Water permeability of self-consolidating concrete", Proc., 11th Int. Congr. Chem. of Cem., Durban, South Africa, (2003), Grieve G. and Owens G. Editors, 1574-1584.

[8] Anagnostopoulos N. and Sideris K.K., "Assessment and Comparison of Transport Properties in Order to Evaluate the Potential Durability of Self Compacting and Conventional Concretes", Proc., Sixth Int. RILEM Symp. on SCC and Fourth North American Conference on the Design and Use of SCC, Montreal, Canada, (2010), Khayat K. and Feys D. Editors, 1005-1012.

[9] Sideris, K.K., Manita, P., Chaniotakis, E., "Performance of thermally damaged fibre reinforced concretes", Construction and Building Materials, Vol. 23, No 3, (2009), 1232-1239.

[10] Kalifa, P., Menneteau, F-D, Quenard, D., "Spalling and Pore Pressure in HPC at High Temperatures", J. Cem. and Concr. Res., Vol. 30 (12), (2000), 1915-1927.

[11] Noumowe, A., Clastres, P., Debicki, G., Bolvin, M., "Effect of High Temperature on High Performance Concrete $\left(70^{\circ}-600^{\circ} \mathrm{C}\right)$ - Strength and Porosity", Proc., Third CANMET/ACI Intern. Conf. on Durability of Conc., Nice, France, (1994), Malhotra V.M. Editor, 157-172.

[12] Diedrichs, U., Jumppannen, U.-M., Penttala, V., "Behavior of High Strength Concrete at High Temperatures", Espoo 1989, Helsinki University of Technology, Department of Structural Engineering, Report 92, (1992), 15-26.

[13] Sanjayan, G. Stocks, L. J. "Spalling of High Strength Silica Fume Concrete in Fire”, ACI Mat. J., Vol 90 (2), (1993), 170-173.

[14] Lin, Wei-Ming, Lin, T.D., Powers-Couche, L.J., "Microstructures of Fire-Damaged Concrete", ACI Mat. J., Vol. 93(3), (1996), 199-205.

[15] Breitenbucker R., High Strength Concrete C 105 with Increased Fire Resistance due to Polypropylene Fibers, F. de Larrad, R. Lacroix (eds), 4th International Symposium on the Utilization of High Strength/High Performance Concrete, Paris, (1996), 571-577.

[16] Sarvaranta L., and Mikkola E., "Fibre Mortar Composites under Fire Conditions: Effect of Ageing and Moisture Content”, Mat. and Str. Vol. 27 (1994), 532-538.

[17] Nishida A., Yamazaki N., Inoue H., SchneiderU. and Diederichs U., "Study on the Properties of High Strength Concrete with Short Polypropylene Fibres for Spalling Resistance", K. Sakai, N. Banthia, O. E. Gjorv (eds), Proc. of the Symposium Concrete under Severe Conditions 2, Saporo, Japan, (1995), 1141-1150.

[18] Kalifa P., Chene G. and Galle C., "High-Temperature behaviour of HPC with Polypropylene Fibres: From Spalling to Microstructure", J. Cem. and Concr. Res. Vol. 31 (2001), 1487-1499.

[19] Bayasi Z. and Al Dhaher M., "Effect of Exposure to Elevetad Temperature on Polypropylene Fiber-Reinforced Concrete", ACI Mater. J. Vol. 99 (1) (2002) 22-26.

[20] Bilodeau A., Kodur V.K.R. and Hoff G.C., "Optimization of the Type and Amount of Polypropylene Fibres for Preventing the Spalling of Lightweight Concrete Subjected to 
Hydrocarbon Fire", paper presented at the 5th CANMET/ACI International Conference on Recent Advances in Concrete Technology, Singapore, August 2001.

[21] Scaperklaus H., "Woven and Nonwoven Fabrics Made from Polypropelene", VDI-Verlag GmbH, Dusseldorf, (1979), p.16.

[22] Eurocode 2, 1992-1-2: Design of concrete structures - Part 1-2: General rules - Structural fire design, Brussels, Belgium, 2004.

[23] Sideris K., Manita P.: "Residual mechanical characteristics and spalling resistance of fiber reinforced self-compacting concretes exposed to elevated temperatures", Construction and Building Materials, Vol. 41, No 4, (2013), 296-302.

[24] Bostrom L., Jansson R., "Self-compacting concrete exposed to fire". SP Report 2008:53. 6 Boras. Sweden. 2008

[25] Silfwerbrand J., "Swedish Recommendations for Preventing Fire Spalling in Concrete Structures for Civil Engineering Purposes" Proceedings from the 2nd International Workshop on Spalling of Concrete due to Fire Exposure, E.A.B. Koenders and F. Dehn Editors, 5-7 October 2011, Delft, The Nederlands, 427-433.

[26] Arup Group Ltd, Fire resistance of concrete enclosures, Work Package 2: Spalling categories, report for the Nuclear Safety Directorate of the Health and Safety Executive, London, Great Britain, 2005.

[27] Comité Européene de Normalisation, Concrete - Part 1 : Performance, Production and Conformity, EN206-1. (2000).

[28] Comité Européene de Normalisation, Cement - Part 1 : Composition, Specification and Conformity Criteria for Common Cements, EN197-1. (2000).

[29] EFNARC, European Guidelines for Self-Compacting Concrete. (2005), http://www.efnarc.org>

[30] RILEM, RILEM TC 116 Technical Recommendation: "Determination of the capillary absorption of water of hardened concrete", J. Mat. and Str., Vol. 32 (4), (1999), 176-179.

[31] Neville A.M., Properties of Concrete, 4th Ed., Longman, (1995), London.

[32] Reinhardt, H.W., Stegmaier, M., "Self-consolidating concrete in Fire", ACI Mat. J., Vol 103 (2), (2006), 130-135.

[33] Phan, L.T, Carino, N.J. "Effect of Test Conditions and Mixture Proportions on Behavior of HighStrength Concrete Exposed to High Temperatures", ACI Mat. J., Vol 99 (1), (2002), 54-66.

[34] Mehta, P.K., Monteiro P.J.M., Concrete: Structure, Properties and Materials, 2nd Ed., Prentice Hall International, New Jersey, (1993), p.139

[35] Phan, L.T., Lawson, J.R, Davis, F.L., "Effects of elevated temperatures exposure on heating characteristics, spalling and residual properties of high performance concrete", J. Mat. and Str., Vol. 34 (No 236), (2001), 83-91.

[36] Uysal M, "Self-compacting concrete incorporating filler additives: Performance at high temperatures", Construction and Building Materials, Vol. 26 (1), (2012), 701-706.

[37] Poon CS, Shui ZH, Lam I, "Compressive behaviour of fiber reinforced high-performance concrete subjected to elevated temperatures, Cement and Concrete Research, Vol. 34 (12), (2004), 2215-22.

[38] Bamonte P., Gambarova P. G. "A study on the mechanical properties of self-compacting concrete at high temperature and after cooling”, Materials and Structures, 45 (2012), 1375-1387.

[39] Persson B, "Fire resistance of self-compacting concrete-SCC". Materials and Structures , 37 (11) (2004), 575-584.

[40] Reinhardt, H.W., Stegmaier, M., "Self-consolidating concrete in Fire”, ACI Mat. J., Vol 103 (2), (2006), 130-135.

[41] Noumowe A, Carre'H, Daoud A, Toutanji H, "High strength self-compacting concrete exposed to fire test", ASCE J Mater Civ Eng 18 (6), (2006), :754-758.

[42] Sideris KK, "Mechanical characteristics of self-consolidating concretes exposed to elevated temperatures" ASCE J Mater Civ Eng 19(8), (2007), 648-654. 